\title{
KRITIK TERHADAP TEORI AKUNTANSI POSITIF
}

\author{
Zulkarim Salampessy \\ Universitas Brawijaya \\ Jl. Veteran Malang 65145 Indonesia
}

\begin{abstract}
Theory is a set of principles of hypothesis, conceptual and pragmatic, which is connected to one another, forming a frame of reference for an area of knowledge. Accounting theory is defined as a logical reasoning in the form of a set of principles or the principles that (1) is a frame of reference to assess the accounting practices and (2) guidelines for the development of practices and procedures are new. normative accounting theory (prescription) is a statement or proposition that requires or require accountants in accounting practices. Positive accounting theory (description) aims to explain and predict accounting practice. Main problem is that current accounting practices and management attitudes towards such practices. Positive accounting theory realist ontology adopted a strong understanding and this determines epistemology and methodology. Methodologically, this is a positivist or modernism, it is committed to using methods of physics. As a result of this is rooted in empirical epistemology. Positive accounting theory bersandarkan utility maximization which has a central assumption of neo-classical ie, each individual has a goal to pursue personal interests. Thus there are several things that need to be done or that the theory should be developed to overcome the weakness of positive accounting theory. Not the goal to replace the existing positive theories, but to complement the existing deficiencies in order to improve the positive accounting theory in order to provide meaningful value. Proposed alternatives are: Integrated Utility, Value Free to Value Laden, S-Matrix Theory, Extention Maximation.
\end{abstract}

Keywords: Theory of Accounting, Accounting Theory Normative, Positive accounting theory

Teori menurut Tuanakotta (1984:1) adalah seperangkat azas hipotesis, konseptual dan pragmatis yang terjalin satu sama lain, yang membentuk suatu kerangka acuan untuk suatu bidang pengetahuan. Gaffikin (2008:57-68) menjelaskan, secara umum, teori-teori memberikan dasar beralasan untuk tindakan - untuk praktik. Sehingga, secara luas proses teori didesain untuk mendapatkan sebuah pengertian dan kemudian memberikan penjelasan fenomena yang berfungsi 
sebagai dasar praktik. Sedangkan Suwardjono (2005:21) menyatakan, teori dapat pula diartikan sebagai suatu penalaran logis (logical reasoning) yang melandasi praktik (berupa tindakan, kebijakan, atau peraturan) dalam kehidupan nyata.

Dari pengertian di atas, teori merupakan sebuah proses yang didesain menjadi seperangkat azas hipotesis, konseptual dan pragmatis yang saling berhubungan yang menjadi pengertian yang berfungsi sebagai dasar untuk menilai praktik dan menjelaskan fenomena yang sedang terjadi maupun fenomena yang akan terjadi.

Atas dasar pengertian di atas, Tuanakotta lebih lanjut mendefinisikan teori akuntansi sebagai suatu penalaran logis dalam bentuk seperangkat azas atau prinsip yang (1) merupakan kerangka acuan untuk menilai praktik-praktik akuntansi dan (2) pedoman bagi pengembangan praktik-praktik dan prosedur yang baru. Suwardjono (2005:2) menyatakan hal yang sama, teori akuntansi menjadi landasan untuk memecahkan masalah-masalah akuntansi secara beralasan atau bernalar yang secara etis dan ilmiah dapat dipertanggungjawabkan.

Dengan demikian dapat dijelaskan bahwa teori akuntansi merupakan sebuah proses yang didesain menjadi seperangkat azas hipotesis, konseptual dan pragmatis yang saling berhubungan yang menjadi pengertian yang berfungsi sebagai dasar atau kerang acuan untuk menilai praktik-praktik akuntansi dan menjadi pedoman bagi pengembangan praktik-praktik dan prosedur akuntansi yang baru serta menjelaskan fenomena yang sedang terjadi maupun fenomena yang akan terjadi. Teori akuntasi sebagaimana dijelaskan di atas ada yang bersifat normatif (preskripsi) dan positif (deskripsi). 
Teori akuntansi normatif berusaha menjelaskan bagaimana dan apa yang seharusnya dipraktikkan dalam akuntansi. Deegan (2004:203) menjelaskan:

Normative theories prescribe how a particular practice should be undertaken and this prescription might be a significant departure from existing practice. A normative theory is generated as a result of the particular theorist applying some norm, standar, or objective against which actual practice should strive to achieve.

Ghozali dan Chariri (2007:35) menyatakan hal yang sama sebagai berikut:

Teori normatif berusaha memberikan pedoman apa yang seharusnya dilakukan berdasarkan pertimbangan nilai (value judgment) yang digunakan dalam merumuskan teori. Teori normatif sering dinamakan teori a priori (artinya sebab ke akibat, atau bersifa deduktif). Alasannya, teori normatif bukan dihasilkan dari penelitian empiris, tetapi dihasilkan dari kegiatan "semi research". Teori normatif hanya menyebutkan hipotesis tentang bagaimana sesuatu seharusnya dipraktikkan, tanpa menguji hipotesis tersebut.

Lebih lanjut Ghozali dan Chariri (2007: 53) menjelaskan bahwa:

Akuntansi cenderung dikembangkan atas dasar pertimbangan nilai (value judgment), yang dipengaruhi oleh faktor lingkungan tempat akuntansi dipraktikkan. Teori tersebut kemudian dituangkan dalam bentuk kebijakan sebagai landasan dalam praktik akuntansi.

Suwardjono (2005:1) menyatakan hal yang sama sebagai berikut:

Akuntansi yang dipraktikkan dalam suatu wilayah negara sebenarnya tidak terjadi begitu saja secara alamiah tetapi dirancang dan dikembangkan secara sengaja untuk mencapai tujuan sosial tertentu.

Dari pengertian di atas, teori normatif berusaha menjelaskan informasi akuntansi apa yang seharusnya dikomunikasikan kepada para pemakai informasi akuntansi dan bagaimana informasi akuntansi akan disajikan. Jadi teori akuntansi normatif terfokus pada preskripsi (norma) dan tidak dimaksudkan untuk pengembangan teori, yang diarahkan untuk menjelaskan dan menjawab pertanyaan tentang "apa dan bagaimana seharusnya dilakukan” oleh akuntan. 
Suwarjono (2005:27) menjelaskan bahwa:

Sasaran teori akuntansi normatif hanyalah menghasilkan penjelasan mengapa perlakuan akuntansi lebih baik atau lebih efektif dibandingkan dengan perlakuan akuntansi lainnya, karena "tujuan akuntansi tertentu" harus dicapai. Sebagai contoh, apakah historical cost accounting lebih baik dari current cost accounting untuk mencapai tujuan akuntansi. Untuk menjelaskan hal tersebut teori akuntansi normatif mengacu pada dasar "tujuan yang telah disepakati untuk dicapai". Tentunya dalam hal ini teori normatif penuh sarat dengan nilai (value laden), karena untuk menentukan suatu praktik sesuai dengan tujuan yang telah ditetapkan untuk dicapai merupakan proses subjektif yang melibatkan kemampuan menimbang (art) antara asas manfaat dan resiko.

APB statement No 4 (1966) menyatakan hal yang sama sebagai berikut;

Bahwa karakteristik dan batasan akuntansi keuangan dan persyaratan keuangan, salah satunya adalah pelaporan historis. Akuntansi dan pernyataan keuangan bersifat historis di mana informasi tentang kejadian merupakan data dasar akuntansi keuangan dan pernyataan keuangan.

Juga oleh American Accounting Association (1977) menyatakan hal yang sama sebagai berikut:

Bahwa tujuan penentuan standar akuntansi adalah memberikan dasar penilaian validitas atau kecukupan metode akuntansi dikaitkan dengan informasi yang dihasilkan, dan menyediakan mekanisme untuk menentukan tingkat ketaatan yang diperlukan dari suatu informasi untuk tujuan tertentu.

Dengan demikian dapat dikatakan bahwa hasil akhir dari teori akuntansi normatif adalah suatu pernyataan atau proposisi yang mengharuskan atau mewajibkan dalam praktik akuntansi. Sebagai contoh, teori akuntansi normatif akan menghasilkan pernyataan bahwa aset tetap harus dinilai, dicatat dan dilaporkan dalam neraca atas dasar biaya historis.

Watts dan Zimmmerman dalam Budiarto dan Murtanto (1999) menjelaskan bahwa dasar pemikiran untuk menganalisis teori akuntansi dalam pendekatan normatif terlalu sederhana dan tidak memberikan dasar teoritis yang 
kuat. Untuk mengurangi kesenjangan dalan teori akuntansi normatif, maka Watts dan Zimmerman mengembangkan pendekatan positif yang lebih lebih berorientasi pada penelitian empiris untuk menjustifikasi beberapa teknik atau metode akuntansi yang sekarang digunakan atau mencari model baru untuk pengembangan teori akuntansi di kemudian hari.

Hendriksen dan Sinaga (1994) menjelaskan bahwa teori-teori normatif bersifat parsial dan dimaksudkan untuk mendukung kesimpulan mengenai prosedur-prosedur khusus saja. Sudah lama dirasakan kebutuhan untuk mengembangkan kerangka teori akuntansi untuk mendorong pengembangan secara logis prinsip dan praktik akuntansi dan untuk menilai praktik-praktik yang sedang berjalan.

Hery (2009:131) mengatakan bahwa:

Teori akuntansi positif merupakan studi lanjut dari teori akuntansi normatif karena kegagalan normatif dalam menjelaskan fenomena praktik yang terjadi secara nyata.

Alasan yang mendasari kemunculan teori akuntansi positif menurut

Ghozali dan Chariri (2007:4) bahwa:

pendekatan normatif yang telah berjaya selama satu dekade tidak dapat menghasilkan teori akuntansi yang siap pakai dalam praktik sehari-hari. Sebagai akibatnya muncul anjuran untuk memahami secara deskriptif berfungsinya ssstem akuntansi di dalam praktik nyata. Alasan lain adalah 'move' komuniti peneliti akuntansi yang menitikberatkan pada pendekatan ekonomi dan perilaku.

Mardiyah (2006:49) menyatakan bahwa:

Teori akuntansi positif berusaha untuk menjelaskan fenomena akuntansi yang diamati berdasarkan pada alasan-alasan yang menyebabkan terjadinya suatu peristiwa. Dengan kata lain teori akuntansi postif dimaksudkan untuk menjelaskan dan memprediksi konsekuensi yang 
terjadi jika manajer menentukan pilihan tertentu. Penjelasan dan prediksi dalam teori akuntansi positif didasarkan pada proses kontrak atau hubungan keagenan.

Teori akuntansi positif menurut Watts dan Zimmerman dalam Deegan (2004 :203) menyatakan hal yang sama sebagai berikut:

...is concerned with explaining accounting practice. It is designed to explain and predict which firms will not use a particular method... but it says nothing as to which method a firm should use.

Scott (2009:284-294) menjelaskan bahwa teori akuntansi positif adalah berkenaan dengan prediksi beberapa perusahaan akan merespon pengajuan standar akuntansi yang baru. Dari pengertian di atas, teori akuntansi positif bertujuan untuk menjelaskan dan memprediksi praktik akuntansi. Menjelaskan alasan mengapa suatu praktik akuntansi dilakukan, misalnya teori akuntansi positif menjelaskan mengapa beberapa perusahaan lebih suka menggunakan metode FIFO dibandingkan menggunakan meotde LIFO. Memprediksi berarti teori harus mampu memprediksi berbagai fenomena praktik yang belum dijalankan. Fenomena yang belum dijalankan tidak selalu fenomena yang akan datang, tetapi fenomena yang telah terjadi tetapi belum ada bukti secara empiris untuk menjustifikasi fenomena tersebut.

Belkaoui (2000) menjelaskan bahwa bagi mereka yang mengadopsi paradigm positif, masalah pokoknya adalah praktik akuntansi yang berjalan dan sikap manajemen terhadap praktik-praktik tersebut. Pendukung pandangan ini berargumen, secara umum, bahwa teknik tersebut dapat diturunkan dan dibenarkan atas dasar penggunaan mereka yang telah teruji atau bahwa manajemen memainkan peran sentral dalam menentukan teknik-teknik yang akan diimplementasikan. Konsekuensinya, tujuan riset akuntansi yang berkaitan dengan 
paradigm positif adalah untuk memahami, menjelaskan dan memprediksi praktik akuntansi yang berjalan.

Gaffikin (2008:57-68) menjelaskan bahwa teori akuntansi positif adalah ekspresi dari teori ekonomi neoklasik. Dasarnya adalah sebuah keyakinan dalam teori pilihan yang rasional, yakni kepentingan pribadi - material yang disebut sebagai perilaku oportunistik. Lebih lanjut dikatakan bahwa secara ontologis riset empiris - toeri akuntansi positif mengadopsi paham realisme. Secara metodologis, ini adalah positivis atau modernisme, berarti berkomitmen menggunakan metode ilmu fisika. Pondasi epistemologis teori akuntansi positif adalah empirisme.

Deegan (2004:204) menjelaskan bahwa teori akuntansi positif, seperti yang dikembangkan oleh Watts dan Zimmerman dan lain-lain, berdasarkan pada asumsi berbasis perekonomian sentral, semua tindakan individu dikendalikan oleh kepentingan diri dan bahwa individu akan bertindak dengan cara oportunistik pada tingkat di mana tindakan akan meningkatkan kesejahteraan mereka.

Dengan menggunakan pendekatan yang bersumber dari positivisme, penelitian-penelitian empiris akuntansi dikembangkan untuk mendukung dan membenarkan berbagai metode atau praktik akuntansi dalam dunia nyata. Kemudian hasil dari penelitian empiris tersebut adalah berupa pernyataan atau proposisi yang nantinya menjadi teori akuntansi positif. Riduwan (2007) mengatakan bahwa:

Teori akuntansi positif mengemukakan proposisi-proposisi yang tidak lain adalah deskripsi tentang praktik-praktik akuntansi dalam dunia nyata, misalnya, (1) karakteristik entitas yang memilih untuk menerapkan metode akuntansi tertentu, dan (2) dampak penerapan standar akuntansi terhadap perilaku manusia atau entitas yang berkepentingan terhadap informasi akuntansi. 


\section{PEMBAHASAN}

Pertama, teori akuntansi positif tidak memberikan resep dan oleh karena itu tidak menyediakan sarana untuk memperbaiki praktik akuntansi. Howieson dalam Deegan (2004:202-240) memberikan sebuah pandangan bahwa dengan gagal menyediakan resep, teoritisi akuntansi positif dapat memisahkan diri mereka dari praktik akuntan.

Kedua, teori akuntansi positif tidak bebas nilai, seperti yang ditegaskan. Jika kita melihat beragam penelitian yang memakai PAT, kita akan melihat tidak adanya rumusan, yaitu tidak adanya pedoman seperti apa yang harus dilakukan. Hal ini dibenarkan oleh teoritisi akuntansi positif dengan mengatakan bahwa mereka tidak ingin memaksakan pandangan mereka pada orang lain tapi lebih suka memberikan informasi tentang implikasi yang diharapkan dari tindakan tertentu dan membiarkan orang untuk memutuskan sendiri apa yang harus mereka lakukan. Sebagai misal, mereka mungkin menyediakan bukti untuk mendukung sebuah prediksi bahwa organisasi yang mendekati kesepakatan hutang berbasis akuntansi akan memakai metode akuntansi yang meningkatkan keuntungan dan aset mereka yang dilaporkan.

Riduwan (2007) mengajukan pertanyaan apakah teori akuntansi positif bebas nilai? Jawaban atas pertanyaan tersebut dijelaskan melalui analisis bahwa toeri akuntansi positif merupakan hasil perekayasaan (engineering) dari teori akuntansi normatif. Artinya riset akuntansi positif dilakukan dengan menggunakan mind set teori normatif. Jadi teori akuntansi positif tidak mungkin bebas nilai. Dalam hal ini, Suwarjono (2005:29) mengatakan: 


\begin{abstract}
Akuntansi keuangan yang di kenal luas sekarang ini dikembangkan atas dasar premis bahwa investor dan kreditor adalah pihak yang dituju oleh informasi akuntansi. Dengan demikian dapat dijelaskan bahwa baik teori normatif maupun positif, keduanya mengemukakan proposisi bahwa informasi akuntansi merupakan masukan dalam pengambilan keputusan investor dan kreditor, yang disampaikan melalui media laporan keuangan. Selain itu, pesan (informasi akuntansi) yang disampaikan melalui laporan keuangan adalah profitabilitas, likuiditas dan solvabilitas. Oleh karenanya proposisi yang dihasilkan teori akuntansi positif adalah tidak bebas nilai.
\end{abstract}

Untuk menjamin obyektivitas hasil riset empiris, maka dimensi-dimensi yang mewakili obyek harus dapat diukur atau dikuantifikasikan oleh subjek. Hardiman dalam Riduwan (2007) menyatakan bahwa suatu obyek dianggap obyektif kalau pemikiran lebih dari satu subyek adalah sama dalam memandang sebuah obyek. Dengan demikian dapat dijelaskan bahwa penentuan indikator (proksi) variabel penelitian dan metode pengukurannya merupakan proses subyektif karena didasarkan pada pertimbangan dan kepentingan tertentu sehingga teori akuntansi positif tidak dapat dikatakan bebas nilai.

Teori akuntansi normatif manyatakan bahwa praktik akuntansi harus menggunakan dasar akrual, sementara teori akuntansi positif mengemukakan proposisi (sebagai hasil riset empiris) bahwa respon investor terhadap informasi arus kas adalah lebih baik dibandingkan informasi laba. Artinya bahwa teori akuntansi positif tersebut sesungguhnya mengandung kepentingan yaitu ingin memberikan "penilaian". Jadi dalam konteks ini pun teori akuntansi normatif tidak bebas nilai.

Berdasarkan paparan di atas jelas bahwa teori akunatnsi positif tidak bebas nilai (value free) sebaliknya sarat dengan nilai (value laden). Klaim bahwa teori akuntansi positif bebas nilai adalah sebuah bentuk ideologi untuk menutupi kenyataan. Gaffikin (2008:57-68) menyatakan bahwa banyak peneliti akuntansi di sekolah bisnis Amerika Serikat, dengan sebuah komitmen ideologis untuk memelihara dogma ekonomi neoklasik.

Ketiga, teori akuntansi positif memiliki asumsi dasar bahwa semua tindakan dikendalikan oleh keinginan untuk memaksimalkan kesejahteraan seseorang. Bagi banyak peneliti asumsi seperti itu menunjukan perspektif yang terlalu negatif dari manusia. Pendapat tentang kesetiaan, moralitas dan 
semacamnya tidak dimasukan dalam teori (karena mereka tidak memasukan dalam teori ekonomi akuntansi lainnya). Hakekatnya manusia adalah makhluk individu sekaligus makhluk sosial. Hal ini merupakan pandangan dasar yang menjelaskan manusia selain akan memperhatikan kepentingan individu, juga mempunyai tanggung jawab untuk memperhatikan kepentingan orang banyak.

Secara ontologi riset neo empiris mengadopsi paham realis yang kuat dan ini menentukan epistemologi dan metodologi yang digunakan. Secara metodologis, ini adalah positivis atau modernisme, berarti ini berkomitmen untuk menggunakan metode ilmu fisika. Akibatnya ini sangat berakar pada epistemologi empiris. Menurut Tafsir (2008:23-28) menjelaskan bahwa:

Kerjasama empirisme dan rasionalisme atau rasionalisme dan empirisme inilah yang melahirkan metode sains (scientific method), dan dari metode inilah lahir pengetahuan sains (scientific knowledge). Kebenaran diperoleh dengan akal, didukung dengan bukti empiris yang terukur. "Terukur" itulah sumbangan positivisme. Lebih lanjut dijelaskan dengan menyadari keterbatasan indera (empirisme) dan akal (rasionalisme) maka diperlukan kemampuan intuisi manusia. Kemampuan inilah yang dapat memahami kebenaran yang utuh, yang tetap dan unique.

Ritzer dan Goodman (2007) menjelaskan bahwa Auguste Comte sebagai bapak positivisme, mengembangkan teori evolusinya atau hukum tiga tingkatan. Teorinya mengatakan bahwa tidak hanya dunia, kelompok masyarakat, ilmu pengetahuan, individu,dan bahkan pemikiran akan berkembang melampaui tahap teologi dan tahap metafisik dan mencapai puncak pada tahap positivistic yang ditandai dengan keyakinan terhadap ilmu sains (science). Manusia mulai menghentikan penyelidikan terhadap penyebab absolut (Tuhan atau alam) dan memusatkan penelitian pada pengamatan terhadap alam fisik dan dunis sosial guna mengetahui hukum-hukum yang mengaturnya. 
Kedua, adanya komitmen ideologis untuk memelihara dogma ekonomi neoklasik. Meletakkan pembahasan PAT sebagai bagian akuntansi dalam tataran pragmatis. Teori akuntansi pragmatis memusatkan perhatiannya pada pengaruh informasi terhadap perubahan perilaku pemakai informasi akuntansi. Dengan kata lain, teori ini membahas reaksi pihak yang dituju oleh informasi akuntansi

\section{Solusi untuk Teori Akuntansi Positif}

Dari beberapa kritik yang diajukan terhadap teori akuntansi positif, maka Ekowati (2006) menjelaskan beberapa hal yang dapat mengatasi kelemahan teori akuntansi positif. Pertama, integrated utility. Kontribusi utility of knowledge of accounting research menurut Watts dan Zimmerman perlu diperluas menjadi integrated utility, yaitu kontribusi yang dalam bentuk multidimensi dan multi arah. Tidak hanya bersifat linier dan selalu dependensi dan satu arah atau beberapa arah yang membentuk parsial utility. Harus integrated utility, sehingga akuntansi tidak terjebak pada konteks pragmatis saja. Misalnya dalam penelitian positivism, apabila ada variabel yang tak signifikan secara statistik, maka jangan langsung berkesimpulan bahwa variabel itu tidak mempunyai utility dan tidak sesuai dengan teori. Persoalannya jangan dilihat sampai di situ saja, tetapi harus digali lebih dalam dengan berbagai pendekatan dan penjelasan, bahkan sampai melihat ada apa dibalik tidak signifikansinya variabel tersebut. Tidak hanya dengan rasio tetapi bias dengan intuisi sehingga dapat menghasilkan penelitian integrated utility, yaitu kontribusi dalam bentuk multidimensi dan multi arah.

Kedua, value free to value laden. Ilmu pengetahuan termasuk akuntansi, tidaklah bebas nilai, tapi sarat dengan nilai yang dapat mempengaruhi akuntansi. Akan ada pengaruh yang muncul ketika nilai sosiologis-psikologis bersentuhan 
dengan hasil yang diperoleh akuntan dalam bentuk laporan keuangan. Chua (1986) mengatakan bahwa akuntansi bukan hanya dipandang sebagai rasional teknik saja, suatu aktivitas jasa yang terpisah dari hubungan kemasyarakatan. Watts dan Zimmerman sendiri akhirnya mengakui pentingnya nilai dalam menentukan riset: preperensi peneliti dan pengguna mempengaruhi proses itu.

Triyuwono (2000) mengungkapkan kritik dan keprihatinannya atas pola pikir serta budaya barat yang rasional materialistik yang juga menjadi landasan teori akuntansi positif, yaitu: budaya barat yang rasional dan materialistik dalam pola pikir Cartesian dan Newtonian memang memberikan dasar pemikiran yang untuk memarjinalkan atau memisahkan nilai-nilai feminin dari nilai-nilai maskulin. Bagi budaya ini, memadukan nilai-nilai maskulin dan feminine, atau memadukan dua hal yang berbeda (kontradiksi dan paradoks) merupakan konsep yang sangat membingungkan. Budaya ini hanya mengenal tentang konsep bagaimana merasakan senang tanpa merasakan sedih, sehat tanpa sakit, kaya tanpa miskin. Konsekuensi dari cara pandang ini adalah dua hal yang kontradiktif (opposites) tadi bersifat dualistic dan mutually exclusive (saling meniadakan). Akibat selanjutnya adalah terciptanya ketidakseimbangan secara permanen yang mengancam kesinambungan (survival), pertumbuhan (growth), dan keutuhan (wholeness) kehidupan manusia, baik secara fisik, mental, maupun spiritual.

Ketiga, S-Matrix theory. Akuntansi mirip studi kealaman, maka s-matrix theory dari Geoffrey Chew yang merupakan gagasan teknik dari filsafat bootstrap. Filsafat bootstrap Capra dalam Ekowati (2006) adalah teori puncak fisika kuantum dengan kesadaran kesalinghubungan esensial dan universal, memperoleh unsur dinamisnya dari teori relativitas dan dirumuskan dalam konteks probabilitas 
reaksi dalam teori s-matrix. S-matrix theory memadukan konsep kuantum dan relativitas layak dipertimbangkan untuk memahami sifat-sifat informasi akuntansi sebagai representasi simbolik reaksi partikel (investor) yang dideskripsikan dalam konteks kecepatan (momentum) investor bermain di bursa saham.

Keempat, extension maximation. Tidak hanya memaksimalkan kepentingan individu yang hanya didahulukan yang secar konvensional dalam bentuk laporan laba rugi, tetapi harus ada perluasan konsep utilitas yaitu: value added, mandatory charity, atau konsep laba yang lain, misalnya laba humanis, yaitu tafsir social atas konsep laba. Bahwa kesejahteraan tidak hanya ditujukan kepada pemegang saham saja seperti yang terlihat dalam konsep laporan laba rugi dan laporan perubahan ekuitas, tetapi maksimasi juga ditujukan kepada stakeholder secara keseluruhan.

\section{KESIMPULAN}

Konsep teori akuntansi postif dikembangkan dalam riset dan literatur akuntansi baru mulai tahun 1960an. Berarti bahwa konsep tersebut masih relativ baru dan masih memerlukan kajian dan penelitian lebih lanjut dalam usaha untuk mendesain teori akuntansi yang lebih bermakna. Sebelum itu riset dan kajian literature akuntansi masih didominasi oleh teori akuntansi normatif. Dalam teori akuntansi normatif, penyusunan standar atau teknik akuntansi lebih banyak bersifat preskriptif dan tidak memperhatikan adanya pengujian hipotesis secara empiris terhadap standar atau metode tersebut. Sedangkan dalam teori akuntansi positif, penekanan lebih banyak kepada hasil pengujian secara empiris untuk menjustifikasi pernyataan yang telah dihipotesiskan. 
Teori akuntansi positif secara ontologi mengadopsi paham realis yang kuat dan ini menentukan epistemologi dan metodologi yang digunakan. Secara metodologis, ini adalah positivis atau modernisme, berarti ini berkomitmen untuk menggunakan metode ilmu fisika. Akibatnya ini sangat berakar pada epistemologi empiris. Teori akuntansi positif bersandarkan utility maximization yang memiliki asumsi sentral neo klasik yaitu setiap individu memiliki tujuan untuk mengejar kepentingan pribadi. Epistemologi pemikiran ilmu pengetahuan modern biasa lebih menekankan pada analisa dibandingkan dengan sintesis. Analisa merupakan proses berpikir memecah atau mengurai realitas utuh menjadi bagian-bagian kecil yang terpisah. Dengan cara dianalisa, kemudian bagian-bagian kecil ini diharapkan dapat menjelaskan realitas yang utuh. Sebaliknya sintesis merupakan proses berpikir dengan menggabungkan bagian-bagian yang terpisah, sehingga dengan itu dapat menjelaskan realitas yang utuh.

Dengan demikian terdapat beberapa hal yang perlu dilakukan atau teori yang perlu dikembangkan untuk dapat mengatasi kelemahan teori akuntansi positif. Bukan tujuan untuk mengganti teori positif yang sudah ada tetapi untuk melengkapi kekurangan yang ada guna menyempurnakan teori akuntansi positif agar memberikan nilai yang bermakna. Alternatif yang diajukan adalah: Integrated Utility, Value Free to Value Laden, S-Matrix Theory, Extention Maximation. 


\section{DAFTAR PUSTAKA}

Accounting Principles Board (APB). (1966). Opinion No. 4. Accounting Interpretations. New York: AICPA.

American Accounting Asociation (AAA). (1977). A Statement of Basic Accounting Theory (ASOBAT).

Belkaoui, A. Riahi. (2001). Teori Akuntansi. Terjemahan. Jakarta: Penerbit Salemba Empat.

Budiarto, Arif., \& Murtanto. (1999). Teori Akuntansi: dari Pendekatan Normatif ke Positif. Jurnal Bisnis dan Akuntansi, 1.

Chua, Wai. Fong. (1986). Radical Developments in Accounting Thought. The Accounting Review, LXI (4), 601-632.

Deegan, C. (2004). Financial Accounting Theory. Australia: McGraw-Hill.

Ekowati, H. W. (2006). Kritik Terhadap Positive Accounting theory (PAT) dan Menuju PAT yang Lebih Bernilai. TEMA, 7 (2).

Gaffikin, M. (2008). Accounting Theory - Research, Regulation and Accounting Practice. Australia: Pearson Education.

Ghozali, Imam., \& Anis, Chariri. (2007). Teori Akuntansi. Edisi Ketiga. Semarang: BP-UNDIP.

Hendriksen, E. S., \& M, Sinaga. (1994). Teori Akuntansi. Edisi Keempat. Jakarta: Penerbit Erlangga.

Hery. (2009). Teori Akuntansi. Edisi Pertama. Jakarta: Penerbit Kencana.

Mardiyah, A. A. (2006). Teori Akuntansi: Konsep dan Empiris. Edisi 2. Malang: BP STIE Malangkuseswara.

Riduwan, Akhmad. (2007). Teori Akuntansi: dari Normatif ke Positif, Isu Bebas Nilai, hingga Mitos dan Wacana Redefinisi. TEMA, 8 (1).

Ritzer, George., \& D, J. Goodman. (2007). Teori Sosiologi Modern. Terjemahan. Edisi Keenam. Jakarta: Penerbit Kencana.

Scott, W. R. (2009). Financial Acoounting Theory. Canada: Pearson PrenticeHall.

Suwardjono. (2005). Teori Akuntansi: Perekayasaan Pelaporan Keuangan. Edisi ketiga. Yogyakarta: BPFE. 
Tafsir, Ahmad. (2008). Filsafat umum. Edisi Revisi. Bandung: Penerbit PT. Remaja Rosdakarya.

Triyuwono, Iwan. (2000). Organisasi dan Organisasi Syariah. Yogyakarta: LKiS.

Tuankotta, T. M. (1984). Teori Akuntansi. Edisi Satu. Jakarta: LPFE-UI.

Watts, R. L., \& J, L. Zimmerman. (1990). Positive Accounting Theory: Ten Yaers Perspective. The Accounting Review, 131-156. 